\title{
Pengaruh Aktivitas Berbagi Pengetahuan dan Mediasi Budaya terhadap Kemampuan Inovasi Guru
}

\author{
Masduki Asbari; Dewiana Novitasari \\ Sekolah Tinggi Ilmu Ekonomi Insan Pembangunan \\ Jl. Raya Serang No.Km. 10, Kadu Jaya, Curug, Tangerang, Banten \\ kangmasduki.ssi@gmail.com
}

Article received: July 2020; revised : October 2020 ; accepted : February 2021

DOI : 10.17977/um025v5i12020p50

\begin{abstract}
This study aims to measure the influence of tacit and explicit knowledge on teacher teacher innovation capability in Indonesia mediated by organizational culture. Data collection was carried out by simple random sampling via electronic to a population of teachers in Jabodetabek. The returned and valid questionnaire results were 231 samples. Data processing using SEM method with SmartPLS 3.0 software. The results of this study are tacit knowledge sharing has a positive and significant effect on teacher innovation capability, both directly and through mediating organizational culture. While explicit knowledge sharing only has a positive and significant effect on teacher innovation capability through organizational culture mediation. This novel research is proposing a model to build teacher innovation capability among teachers through tacit \& explicit knowledge sharing with organizational culture as mediation. This research can pave the way to improve teacher readiness in facing the era of education 4.0.
\end{abstract}

Keywords: Education 4.0; Explicit Knowledge; Teacher Innovation Capability; Knowledge Management; Organizational Culture; Tacit Knowledge

\begin{abstract}
Abstrak: Penelitian ini bertujuan untuk mengukur pengaruh tacit dan eksplisit knowledge terhadap kemampuan inovasi guru guru di Indonesia yang dimediasi oleh budaya organisasi. Pengumpulan data dilakukan secara simple random sampling melalui elektronik terhadap populasi guru di Jabodetabek. Hasil kuesioner yang kembali dan valid sebanyak 231 sampel. Pengolahan data menggunakan metode SEM dengan software SmartPLS 3.0. Hasil penelitian ini adalah tacit knowledge sharing berpengaruh positif dan signifikan terhadap kapabilitas inovasi guru, baik secara langsung maupun melalui mediasi budaya organisasi. Sedangkan berbagi pengetahuan eksplisit hanya berpengaruh positif dan signifikan terhadap kemampuan inovasi guru melalui mediasi budaya organisasi. Penelitian baru ini mengusulkan suatu model untuk membangun kapabilitas inovasi guru di antara para guru melalui tacit dan eksplisit knowledge sharing dengan budaya organisasi sebagai mediasi. Penelitian ini dapat membuka jalan untuk meningkatkan kesiapan guru dalam menghadapi era pendidikan 4.0.
\end{abstract}

Kata Kunci: Pendidikan 4.0; Pengetahuan Eksplisit; Kemampuan Inovasi Guru; Manajemen Pengetahuan; Budaya Organisasi; Pengetahuan Tacit

Tantangan baru yang saat ini memengaruhi pendidikan adalah perubahan dramatis yang datang dari industrial revolution 4.0. Revolusi industry ini mempersyaratkan kualitas sumber daya manusia yang lebih mumpuni, agile, adaptif dan responsif terhadap perubahan yang cepat. Dunia pendidikan menghadapi perubahan ekonomi, sosial, politik dan teknologi yang demikian cepat. Oleh karenanya, sekolah harus fleksibel untuk mampu beradaptasi dengan situasi dan konteks yang berubah. Sekolah dan lembaga pendidikan lainnya memerlukan lingkungan yang terus tumbuh positif dan kondusif dalam kompetisi sumber daya manusia global. Oleh karena itu, tak bisa dipungkiri bahwa sekolah memerlukan sinergi antara guru dan lingkungan kerja yang mampu melakukan perbaikan terus-menerus dalam inovasi dan performansi. Intinya adalah di era ekonomi pengetahuan ini muncul masyarakat pengetahuan 
yang memerlukan inovasi dan fleksibilitas sebagai energi untuk bertahan dari persaingan. Oleh karena itu, pembangunan strategis lembaga pendidikan di masa depan adalah pada peningkatan sumber daya pengetahuan, terutama guru, yang membuka ruang inovasi dan pertumbuhan.

Untuk meyakinkan bahwa lembaga pendidikan, khususnya sekolah bisa kompetitif dan adaptif, guru perlu diarahkan dan terlibat dalam memompa performansi sekolah. Guru musti berdaya dan memberdayakan. Alhasil, sekolah harus mewujud menjadi organizational culture yang sesungguhnya. Organizational culture yang memberdayakan guru sebagai salah satu unsur utama transformasi sekolah, sekaligus guru sebagai instrumen peradaban. Bentuk sekolah sebagai organizational culture sangat penting untuk lembaga pendidikan yang beroperasi di lingkungan dengan perubahan cepat dan tak terduga. Sehingga kecepatan respon atas perubahan menjadi syarat mutlak mencetak sumber daya manusia, siswa yang kompetitif dan memenangkan persaingan SDM global (Triwiyanto, Suyanto \& Prasojo, 2019; Hutagalung et al., 2020).

Pengetahun individu guru dan sekolah menjadi modal intelektual yang dengan cepat menjadi icon baru yang menggambarkan nilai ekonomis sebuah sekolah. Inilah paradigma baru yang diadaptasi dari industrial revolution 4.0. Ketergantungan pada asset produktif tradisional seperti gedung, bangunan, tanah dan tangible asset lainnya tidak lagi menjadi sumbangan investasi utama masa depan. Aset produktif dan berkelanjutan di masa depan adalah aset intangible dalam bentuk pengetahuan yang melekat pada guru. Penelitian ini berupaya untuk memahami pengaruh proses belajar dan knowledge sharing (tacit and explicit knowledge) guru di Indonesia yang dikaitkan dengan peningkatan teacher innovation capability mereka.

Knowledge diklasifikasikan menjadi dua jenis meliputi: tacit knowledge dan explicit knowledge (Polanyi, 1966). Definisi tacit knowledge adalah pengetahuan yang masih berada dalam benak manusia dan bersifat sangat personal (Chen et al, 2018; Khoshorour \& Gilaninia, 2018; Perez-Fuillerat et al, 2018), sulit dirumuskan dan dibagi secara natural (Wang \& Liu, 2019) sehingga dalam transformasinya memerlukan interaksi personal (Lee, 2019). Tacit knowledge ini berada dan berakar di dalam tindakan maupun pengalaman seseorang, termasuk idealisme, nilai-nilai, maupun emosionalnya (Hartley, 2018).

Berdasarkan pengertiannya, maka tacit knowledge dikategorikan sebagai personal knowledge atau dengan kata lain pengetahuan yang diperoleh dari individu atau perorangan (Nonaka \& Toyama, 2015; Munoz et al, 2015; Wang et al, 2016; Jou et al, 2016; Rothberg \& Erickson, 2017). Pengalaman yang diperoleh tiap guru tentunya berbeda-beda berdasarkan situasi dan kondisi yang tidak dapat diprediksi. Tacit knowledge sifatnya tidak mudah diartikulasikan dan dikonversi menjadi explicit knowledge (Cairo Battistutti, 2017; Zang et al, 2015). Walaupun demikian, tacit knowledge bisa diberdayakan dengan proses spiralisasi pengetahuan atau SECI Model (Li, Liu \& Zhou, 2018; Hodgins \& Dadich, 2017; Balde et al, 2018).

Explicit knowledge adalah salah satu jenis pengetahuan yang mudah didokumentasikan dan dibentuk (Choi \& Lee, 2003; Sousa \& Rocha, 2019; Wokcik et al, 2019) biasanya merupakan pengetahuan yang melekat pada sekolah (Afsar, Masood \& Umrani, 2019). Selain itu, explicit knowledge dapat dibuat, ditulis dan ditransfer di antara unit kegiatan sekolah (Lombardi, 2019). Transfer explicit knowledge di antara guru lebih mudah didorong oleh mekanisme dan budaya sekolah yang kondusif.

Organizational culture yang baik lebih tahan terhadap krisis (Starbuck, 2017). Dimensi seperti keinginan, disiplin, pengambilan keputusan, dan kesejajaran disajikan sebagai elemen penting pembelajaran organisasi (Urban \& Gaffurini, 2018). Organizational culture juga merupakan indikator kinerja yang penting untuk mengevaluasi kinerja organiasi secara keseluruhan (Qi \& Chau, 2018) yang mampu membantu membangun sumber daya pengetahuan yang diperlukan dan mempertahankan pertumbuhan serta kelangsungan sekolah. Kemampuan akses terhadap pengetahuan adalah faktor pembeda antar sekolah yang satu dengan sekolah yang lainnya. Kesuksesan strategi lembaga pendidikan sekolah sangat signifikan berkaitan dengan basis pengetahuan yang kokoh dan dimiliki oleh setiap insan lembaga pendidikan sekolah.

Era indusri 4.0 saat ini memerlukan teacher innovation capability sebagai keunggulan kompetitif sekolah (Muscio \& Ciffolili, 2019; Hamada, 2019), competitive strategy (Culot, Orzes \& Sartor, 2019), 
kunci untuk menghadapi era industry 4.0 (Stachova et al, 2019) bagian dari kualitas manajemen abad ke-21 (Gunasekaran, Sabramanian \& Ngai, 2019), banyak memberi keuntungan terhadap bisnis (Parida, Sjodin \& Reim, 2019). Kemampuan inovasi diakui sebagai salah satu sumber daya internal ter penting yang dapat menghasilkan kinerja lembaga pendidikan sekolah yang unggul (Santoro et al, 2017). Inovasi merupakan aspek penting dari pendidikan yang berkualitas (Klaeijsen, Vermeulen, \& Martens, 2017).

\section{METODE}

Metode yang digunakan dalam penelitian ini adalah metode kuantitatif. Dilakukan pengumpulan data dengan mengedarkan angket kepada seluruh guru lembaga pendidikan sekolah. Instrumen yang digunakan untuk mengukur explicit knowledge sharing diadaptasi dari Liebowitz \& Chen (2001) dan Wang \& Wang (2012). Tacit knowledge sharing diadaptasi dari Holste \& Fields (2010), Lin (2006), and Wang \& Wang (2012). Organizational culture diukur dari instrumen yang diadaptasi dari JiménezJiménez and Sanz-Valle (2011). Teacher innovation capability diadaptasi dari Lee \& Choi (2003). Angket didesain tertutup kecuali untuk pertanyaan/pernyataan mengenai identitas responden yang berupa angket semi terbuka. Tiap item pertanyaan/pernyataan tertutup diberikan 5 opsi jawaban, yaitu: sangat setuju (SS) skor 5, setuju (S) skor 4, kurang setuju (KS) skor 3, tidak setuju (TS) skor 2, dan sangat tidak setuju (STS) skor 1. Metode untuk mengolah data adalah dengan PLS dan menggunakan software SmartPLS versi 3.0 sebagai tool-nya.

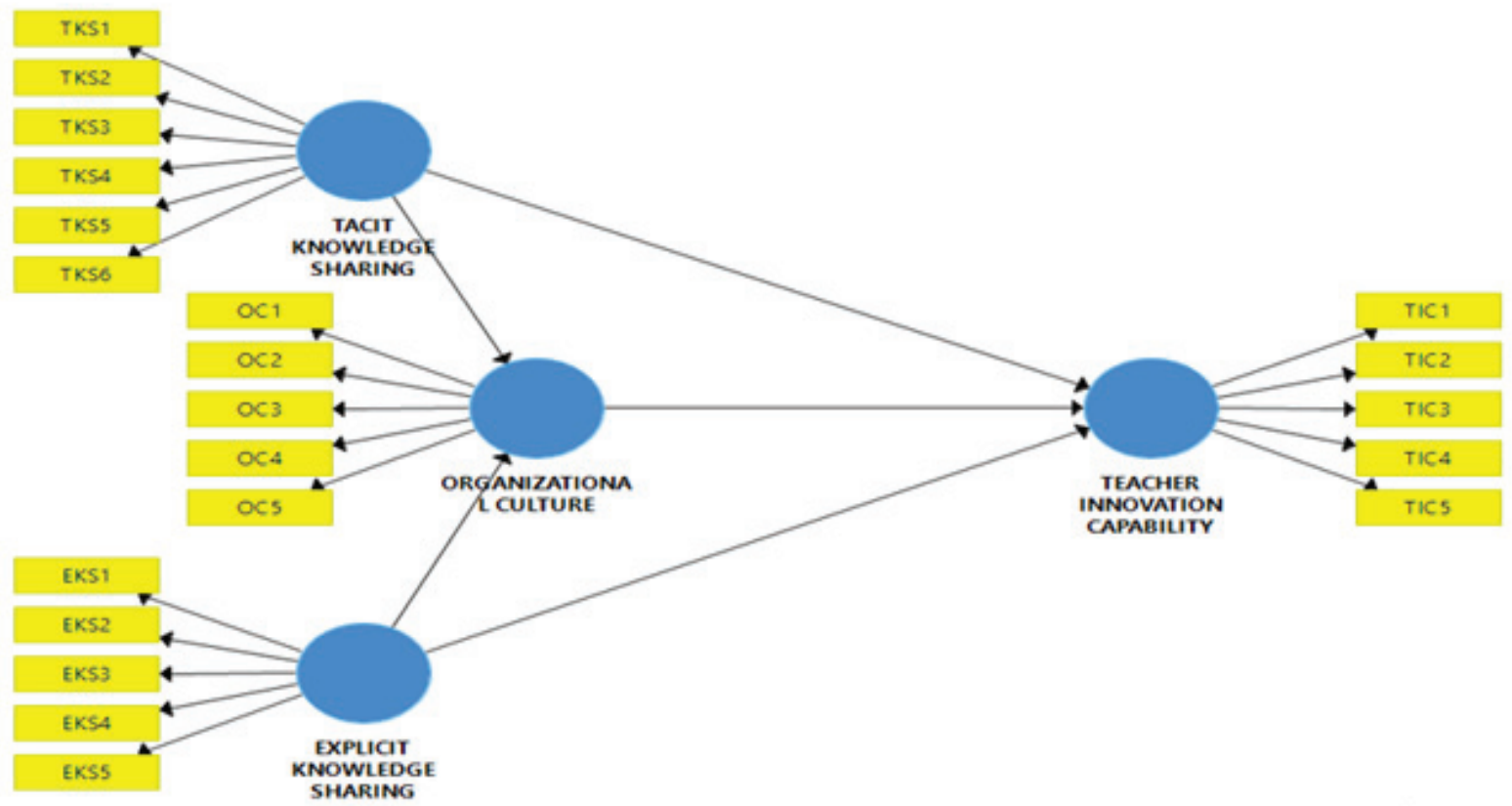

Gambar 1. Model Penelitian

Populasi dalam penelitian ini adalah guru sekolah di Jabodetabek yang jumlahnya belum teridentifikasi secara pasti. Kuesioner disebarkan secara elektronik dengan teknik simple random sampling ke seluruh guru di daerah Jabodetabek. Hasil kuesioner yang kembali dan valid adalah 231 sampel. Gambar 1 memperlihatkan model penelitian. berikut:

Berdasarkan rumusan masalah, telaah teoritis, dan rerangka konseptual hipotesis penelitian sebagai

H1: Explicit knowledge berpengaruh langsung terhadap teacher innovation capability

H2: Tacit knowledge berpengaruh langsung terhadap teacher innovation capability

H3: Explicit knowledge berpengaruh langsung terhadap organizational culture

H4: Tacit knowledge berpengaruh langsung terhadap organizational culture 
H5: Organizational culture berpengaruh langsung terhadap teacher innovation capability

H6: Explicit knowledge berpengaruh tidak langsung terhadap teacher innovation capability melalui mediasi organizational culture

H7: Tacit knowledge berpengaruh tidak langsung terhadap teacher innovation capability melalui mediasi organizational culture

Pengujian model pengukuran meliputi pengujian convergent validity, discriminant validity dan composite reliability. Pengujian hipotesis dalam PLS disebut juga sebagai uji inner model. Uji ini meliputi uji signifikansi pengaruh langsung dan tidak langsung serta pengukuran besarnya pengaruh variabel eksogen terhadap variabel endogen. Untuk mengetahui pengaruh tacit dan explicit knowledge sharing terhadap organizational culture dan teacher innovation capability dibutuhkan uji pengaruh langsung. Uji pengaruh langsung dilakukan dengan menggunakan uji t-statistik dalam model analisis partial least squared (PLS) dengan menggunakan bantuan software SmartPLS 3.0.

\section{HASIL DAN PEMBAHASAN}

Subyek penelitian dikategorikan atas dasar usia, status guru, masa kerja guru, dan ijazah tertinggi. Tabel 1 memperlihatkan informasi deskriptif subyek penelitian.

Tabel 1. Informasi Deskriptif Subyek Penelitian

\begin{tabular}{lccc}
\hline & Kriteria & Jumlah & \% \\
\hline \multirow{3}{*}{ Usia (per Oktober 2019) } & $<30$ tahun & 49 & $21.33 \%$ \\
& $30-40$ tahun & 119 & $51.69 \%$ \\
& $>40$ tahun & 62 & $26.98 \%$ \\
\hline \multirow{2}{*}{ Status guru } & Public (ASN) & 97 & $41.91 \%$ \\
& Private (Swasta) & 134 & $58.09 \%$ \\
Masa kerja sebagai guru & $<5$ tahun & 48 & $20.95 \%$ \\
& $5-10$ tahun & 127 & $55.08 \%$ \\
& $>10$ tahun & 55 & $23.97 \%$ \\
\hline \multirow{2}{*}{ Ijazah tertinggi } & $<$ S1 & 21 & $9.16 \%$ \\
& $\geq$ S1 & 210 & $90.84 \%$ \\
\hline
\end{tabular}

Tahap pengujian model pengukuran meliputi pengujian convergent validity, discriminant validity dan composite reliability. Hasil analisis PLS dapat digunakan untuk menguji hipotesis penelitian jika seluruh indikator dalam model PLS telah memenuhi syarat validitas konvergen, validitas deskriminan dan uji reliabilitas.

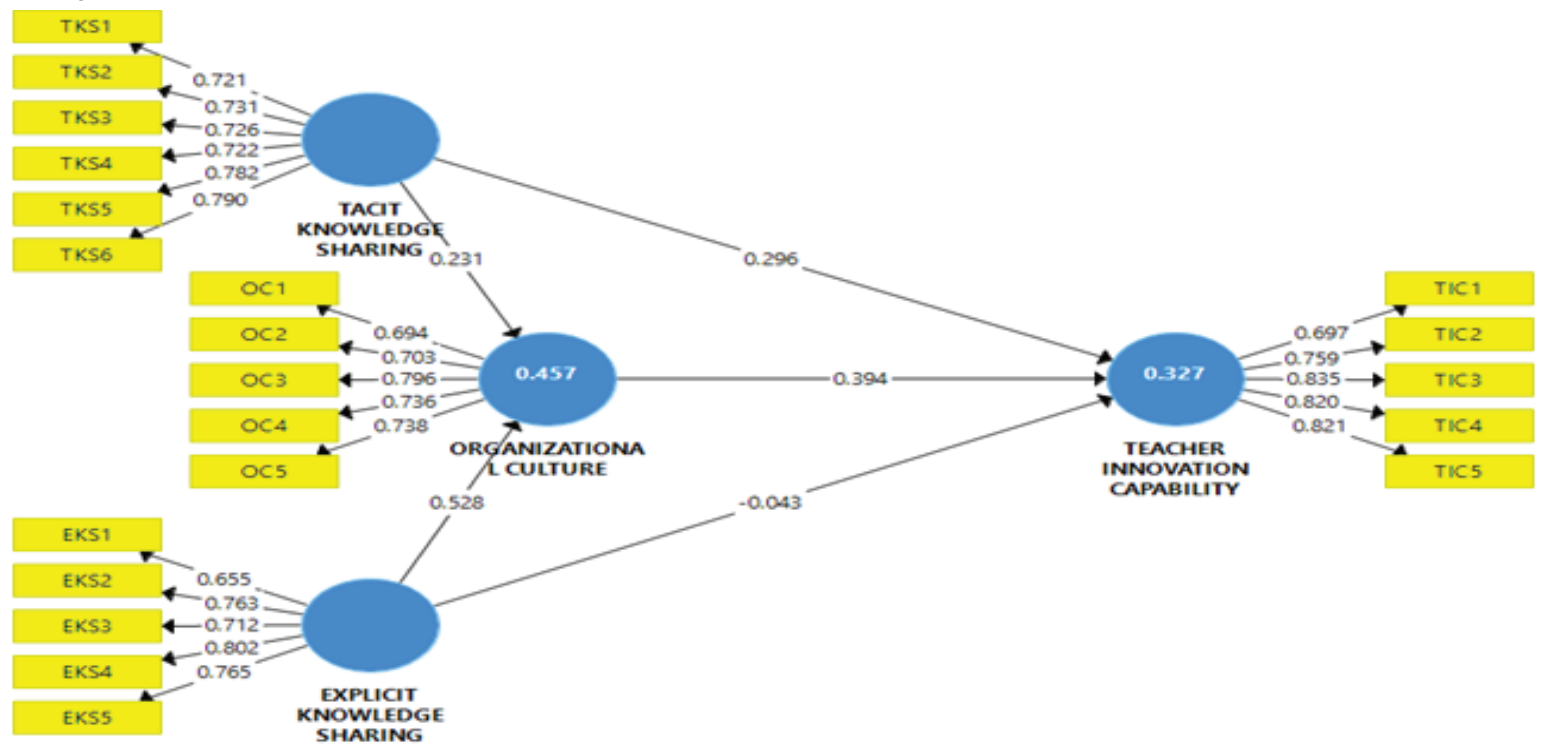

Gambar 2. Estimasi Model Valid 
Uji validitas konvergen dilakukan dengan melihat nilai loading faktor masing-masing indikator terhadap konstruknya. Pada sebagian besar referensi, bobot faktor sebesar 0.5 atau lebih dianggap memiliki validitas yang cukup kuat untuk menjelaskan konstruk laten (Hair et al, 2010; Ghozali, 2014). Pada penelitian ini batas minimal besarnya loading factor yang diterima adalah 0.5 , dengan syarat nilai AVE setiap konstruk > 0.5 (Ghozali, 2014).

Berdasarkan hasil estimasi model PLS pada Gambar 2, seluruh indikator telah memiliki nilai loading factor di atas 0.5 sehingga model telah memenuhi syarat validitas konvergen. Selain dengan melihat nilai loading factor masing-masing indikator, validitas konvergen juga dinilai dari nilai AVE setiap konstruk. Nilai AVE setiap kontruk penelitian ini sudah di atas 0.5 . Jadi validitas konvergen dari model penelitian ini sudah memenuhi syarat. Nilai loadings, cronbach's alpha, composite reliability dan AVE setiap konstruk selengkapnya dapat dilihat pada Tabel 2.

Tabel 2. Items Loadings, Cronbach's Alpha, Composite Reliability, and Average Variance Extracted (AVE)

\begin{tabular}{|c|c|c|c|c|c|}
\hline Varables & Items & Loadings & $\begin{array}{c}\text { Cronbach's } \\
\text { Alpha } \\
\end{array}$ & $\begin{array}{l}\text { Composite } \\
\text { Reliability }\end{array}$ & AVE \\
\hline \multirow{6}{*}{$\begin{array}{c}\text { Tacit Knowledge Shar- } \\
\text { ing (TKS) }\end{array}$} & TKS1 & 0.721 & 0.842 & 0.882 & 0.556 \\
\hline & TKS2 & 0.731 & & & \\
\hline & TKS3 & 0.726 & & & \\
\hline & TKS4 & 0.722 & & & \\
\hline & TKS5 & 0.782 & & & \\
\hline & TKS6 & 0.790 & & & \\
\hline \multirow{5}{*}{$\begin{array}{l}\text { Explicit Knowledge } \\
\text { Sharing }(E K S)\end{array}$} & EKS1 & 0.655 & 0.794 & 0.859 & 0.550 \\
\hline & EKS2 & 0.763 & & & \\
\hline & EKS3 & 0.712 & & & \\
\hline & EKS4 & 0.802 & & & \\
\hline & EKS5 & 0.765 & & & \\
\hline \multirow{5}{*}{$\begin{array}{c}\text { Organizational Culture } \\
(O C)\end{array}$} & OC1 & 0.694 & 0.785 & 0.854 & 0.539 \\
\hline & $\mathrm{OC} 2$ & 0.703 & & & \\
\hline & OC3 & 0.796 & & & \\
\hline & OC4 & 0.736 & & & \\
\hline & OC5 & 0.738 & & & \\
\hline \multirow{5}{*}{$\begin{array}{c}\text { Teacher Innovation } \\
\text { Capability (TIC) }\end{array}$} & TIC1 & 0.697 & 0.846 & 0.891 & 0.621 \\
\hline & TIC2 & 0.759 & & & \\
\hline & TIC3 & 0.835 & & & \\
\hline & TIC4 & 0.820 & & & \\
\hline & TIC5 & 0.821 & & & \\
\hline
\end{tabular}

Discriminant validity dilakukan untuk meyakinkan bahwa setiap konsep dari masing-masing variabel laten berbeda dengan variabel laten lainnya. Model mempunyai discriminant validity yang baik jika nilai kuadrat AVE masing-masing konstruk eksogen (nilai pada diagonal) melebihi korelasi antara konstruk tersebut dengan konstruk lainnya (nilai di bawah diagonal) (Ghozali, 2014). Hasil pengujian discriminant validity dengan menggunakan nilai kuadrat AVE, yakni dengan melihat Fornell-Larcker Criterion Value diperoleh seperti pada Tabel 3.

Hasil uji validitas deskriminan pada Tabel 3 di atas menunjukkan bahwa seluruh konstruk telah memiliki nilai akar kuadrat AVE di atas nilai korelasi dengan konstruk laten lainnya (melalui kriteria Fornell-Larcker) sehingga dapat disimpulkan bahwa model telah memenuhi validitas deskriminan. 
Tabel 3. Discriminant Validity

\begin{tabular}{ccccc}
\hline VARIABLES & EKS & OC & TIC & TKS \\
\hline EKS & 0.741 & & & \\
OC & 0.646 & 0.734 & & \\
TIC & 0.363 & 0.515 & 0.788 & \\
TKS & 0.512 & 0.501 & 0.471 & 0.746 \\
\hline
\end{tabular}

Reliabilitas konstruk dapat dinilai dari nilai cronbach's alpha dan composite reliability dari masingmasing konstruk. Nilai composite reliability dan cronbach's alpha yang disarankan adalah lebih dari 0.7. (Ghozali, 2014). Hasil uji reliabilitas pada tabel 2 di atas menunjukkan bahwa seluruh konstruk telah memiliki nilai composite reliability dan cronbach's alpha lebih besar dari 0.7 ( $>0.7)$. Kesimpulannya, seluruh konstruk telah memenuhi reliabilitas yang dipersyaratkan.

Tabel 4. Nilai $R$ Square

\begin{tabular}{ccc}
\hline & R Square & $\begin{array}{c}\text { R Square Ad- } \\
\text { justed }\end{array}$ \\
\hline OC & 0.457 & 0.455 \\
TIC & 0.327 & 0.323 \\
\hline
\end{tabular}

Pengujian hipotesis dengan teknik boothstrapping, diperoleh nilai $R$ Square dan nilai uji signifikansi sebagaimana Tabel 4.

Berdasarkan Tabel 4 di atas, nilai $R$ Square OC sebesar 0.457 yang berarti bahwa variabel organizational culture (OC) mampu dijelaskan oleh variabel tacit knowledge sharing (TKS) dan explicit knowledge sharing (EKS) sebesar 45.7\%, sedangkan sisanya sebesar 54.3\% dijelaskan oleh variabel lain yang tidak dibahas dalam penelitian ini. Sementara itu, nilai $R$ Square teacher innovation capability (TIC) sebesar 0.327 yang berarti bahwa variabel teacher innovation capability mampu dijelaskan variabel tacit knowledge sharing, explicit knowledge sharing dan organizational culture sebesar $32.7 \%$, sedangkan sisanya sebesar $67.3 \%$ dijelaskan oleh variabel lain yang tidak dibahas dalam penelitian ini. Sedangkan Tabel 5 menampilkan T Statistics dan P-Values yang menunjukkan pengaruh antar variable penelitian yang telah disebutkan.

Tabel 5. Hypotheses Testing

\begin{tabular}{ccccccl}
\hline Hypotheses & Relationship & Beta & SE & $\begin{array}{c}\text { T Statis- } \\
\text { tics }\end{array}$ & V-Values & Decision \\
\hline H1 & EKS -> TIC & -0.043 & 0.054 & 0.810 & 0.418 & $\begin{array}{l}\text { Not Sup- } \\
\text { ported }\end{array}$ \\
H2 & TKS -> TIC & 0.296 & 0.049 & 6.026 & 0.000 & Supported \\
H3 & EKS -> OC & 0.528 & 0.035 & 15.113 & 0.000 & Supported \\
H4 & TKS -> OC & 0.231 & 0.037 & 6.278 & 0.000 & Supported \\
H5 & OC -> TIC & 0.394 & 0.047 & 8.403 & 0.000 & Supported \\
H6 & EKS -> OC -> TIC & 0.208 & 0.030 & 7.033 & 0.000 & Supported \\
H7 & TKS -> OC -> TIC & 0.091 & 0.018 & 5.057 & 0.000 & Supported \\
\hline
\end{tabular}




\section{Pengaruh Tacit dan Explicit Knowledge terhadap Organizational Culture}

Berdasarkan hasil penelitian, dapat diambil kesimpulan bahwa tacit knowledge sharing memberikan pengaruh positif dan signifikan terhadap teacher innovation capability. Baik secara langsung maupun melalui mediasi organizational culture. Artinya bahwa semakin positif tacit knowledge sharing dilakukan oleh guru, maka semakin kondusif pula teacher innovation capability individu guru lembaga pendidikan sekolah. Temuan ini sejalan dengan penelitian terdahulu pada organisasi bisnis, yakni PerezLuno et al (2018), Terhorst et al (2018). Berbeda dengan hal di atas, explicit knowledge sharing tidak berpengaruh signifikan terhadap teacher innovation capability, kecuali melalui mediasi organizational culture. Artinya, organizational culture menjadi full mediation antara explicit knowledge sharing dan teacher innovation capability.

Setiap lembaga pendidikan sekolah harus memanfaatkan tacit knowledge gurunya dengan mendorong untuk berbagi pengetahuan dan terus belajar. Lembaga pendidikan sekolah seperti ini menjadi lebih kreatif, inovatif dan memimpin di era education 4.0. Sekolah dapat memfasilitasi pengelolaan dan penggunaan pengetahuan tacit yang berada di luar kesadaran yang tersimpan di bawah pikiran bawah sadar setiap guru dengan pendekatan embedding dan sharing (Ma et al, 2018).

Hasil penelitian ini juga menyimpulkan bahwa tacit dan explicit knowledge sharing berpengaruh positif dan signifikan terhadap organizational culture. Artinya adalah semakin baik tacit dan explicit knowledge sharing seorang guru, maka semakin positif pembentukan dan pengembangan organizational culture di lembaga pendidikan sekolah. Hal ini sejalan juga dengan kesimpulan penelitian Qi \& Chau (2018) pada organisasi bisnis. Hal ini mengisyaratkan bahwa sumber daya yang terlangka dan terberharga di era digital bukanlah guru biasa dan mediocre, melainkan guru yang dapat menciptakan ide dan inovasi baru (Xu, David \& Kim, 2018). Guru yang memainkan peran kunci dalam memproduksi dan menggunakan kembali pengetahuan dan kekayaan intelektualnya melalui pendidikan dan pengajaran (Al-Kurdi, El-Haddadeh \& Eldabi, 2018). Karena alasan inilah, kelangkaan guru yang memiliki tacit dan explicit knowledge yang memadai dan terampil bisa melumpuhkan daya inovasi, competitiveness, pertumbuhan dan fleksibilitas lembaga pendidikan sekolah. Tak ayal, di masa depan, bakat dan respon guru sekolah dalam proses knowledge sharing mewakili faktor penting masa depan pendidikan bangsa. Guru sekolah dengan ide dan inovasi menjadi barang mewah modal dan instrumen mperadaban.

\section{Pengaruh Organizational Culture terhadap Teacher Innovation Capability}

Di era industri 4.0 saat ini, ditandai dengan kompetisi yang semakin ketat, keberlanjutan tetap menjadi perhatian dan masalah penting. Teacher innovation capability menjadi pendorong keberlanjutan bisnis. Kinerja ini bergantung pada budaya pengetahuan yang tertanan dalam organisasi. Pengetahuan yang terdiri atas tacit dan explicit knowledge. Banyak peneliti membahas teacher innovation capability yang berkesimpulan bahwa innovation dipengaruhi oleh leadership (Choudhary, 2019) knowledge sharing (Kim \& Shim, 2018) knowledge search (Wang, Chen \& Chang, 2019) collaborative culture (Yang, Nguyen \& Le, 2018) dan knowledge process (Imran et al, 2018). Penelitian ini, hendak menguji pengaruh tacit and explicit knowledge terhadap teacher innovation capability guru di lembaga pendidikan sekolah dalam rangka menyongsong industrial revolution 4.0. Peneliti sebelumnya telah membuktikan pengaruh positif dan signifikan tacit dan explicit knowledge terhadap teacher innovation capability (Li et al, 2019). Lebih khusus, banyak peneliti menyimpulkan bahwa tacit knowledge berpengaruh positif dan signifikan terhadap teacher innovation capability (Perez-Luno et al, 2018). Kesemuanya dalam lingkup organisasi bisnis. Namun demikian, ada peneliti yang menyebutkan bahwa formal \& informal learning mempengaruhi teacher innovation capability guru di sekolah (Lecat, Beausaert, \& Raemdonck, 2018)

Learning organization menjadi salah satu strategi bagi organisasi untuk mempelajari dinamika lingkungan usahanya (Zhu et al, 2018). Sekolah dengan rutinitas belajar yang terkelola menghasilkan kumpulan individu yang knowledgeable, baik explicit knowledge maupun tacit knowledge (Hussain et al, 2018). Sebagian peneliti menyimpulan bahwa organizational culture dipengaruhi oleh collaborative culture dan knowledge sharing (Nugroho, 2018). Tacit knowledge ditemukan menjadi predictor yang sangat signifikan bagi pengembangan organizational culture (Muthuveloo, Shanmugam \& Teoh, 2017). 
Penciptaan pengetahuan yang dikondisikan oleh organizational culture memicu dan memacu teacher innovation capability dan kinerja organisasi (Asbari, Purwanto \& Santoso, 2019; Lin \& Lee, 2017). Inovasi sekolah berkesinambungan ketika didasari oleh budaya belajar yang memberi nilai tambah. Budaya belajar inilah yang menjadikan semua guru berinteraksi satu sama lain sehingga pengetahuan mereka saat ini dan pengetahuan baru yang diperoleh dapat secara efektif ditransfer, dipertukarkan dan digabungkan menjadi kecerdasan dan pengetahuan sekolah (Lin \& Lee, 2017). Lingkungan organisasi yang memberikan kegembiraan dalam bekerja merupakan faktor penting dalam menciptakan teacher innovation capability anggota organisasi (Bani-Melhem, Zeffane \& Albaity, 2018).

Berdasarkan temuan penelitian ini juga menyimpulkan bahwa organizational culture berpengaruh positif dan signifikan terhadap teacher innovation capability. Organizational culture juga memediasi pengaruh tacit dan explicit knowledge terhadap teacher innovation capability. Hal ini sesuai dengan kesimpulan Martinez-Costa (2018). Penelitian ini juga menyimpulkan bahwa lembaga pendidikan sekolah bisa mengelola pengalaman masa lalu untuk dikombinasikan dengan tacit dan explicit knowledge yang dimiliki guru saat ini. Intinya, organizational culture mampu memberikan kondisi positif dalam proses penciptaan pengetahuan. Sedangkan knowledge creation dan knowledge management berkaitan erat dengan performance sekolah di era education 4.0 saat ini.

Manajemen lembaga pendidikan sekolah perlu membangun keterlibatan maksimal seluruh guru untuk melakukan knowledge sharing baik dalam bentuk tacit knowledge maupun explicit knowledge. Pelatihan guru di setiap bagian sekolah merupakan kebutuhan dengan tingkat intensitas, konten dan konteks yang disesuaikan dengan key performance indicator masing-masing guru. Intinya, tim learning behavior yang diciptakan di lingkungan sekolah menjadi pendorong inovasi guru (Widmann \& Mulder, 2018).

Proses berbagi pengetahuan untuk membangun teacher innovation capability lembaga pendidikan sekolah hendaknya tidak hanya terbatas pada proses internal sekolah. Tetapi, manajemen sekolah perlu meluaskan proses membangun inovasi ini melalui upaya menyerap, mengartikulasi, memanfaatkan dan mengelola pengetahuan yang bersumber dari mitra eksternal sekolah seperti orang tua siswa, pemerintah, masyarakat, dan lembaga pendidikan lainnya. Manajemen sekolah bisa mengaktifkan learning from others ketika menugaskan gurunya untuk menghadiri training, seminar, workshop, kunjungan ke sekolah lain, bertemu dengan komite sekolah dan mitra strategis lainnya. Karena pengetahuan eksternal, seperti yang berasal dari trainer, coach, orang tua siswa, pemerintah, masyarakat, dan lembaga pendidikan lainnya mendukung daya teacher innovation capability lembaga pendidikan sekolah.

Selain itu, komitmen pembelajaran dan kesungguhan untuk terlibat dalam mengelola lingkungan pembelajaran menjadi hal yang perlu diperhatikan. Karena lembaga pendidikan sekolah bisa menjadi organizational culture tatkala seluruh civitas lembaga pendidikan sekolah merasa menikmati proses pembelajaran ini. Learning process menjadi budaya sekolah yang mendorong inovasi (Asbari, Santoso \& Purwanto, 2019). Faktor kunci organizational culture adalah kepercayaan, komunikasi terbuka, keterlibatan yang tinggi, adanya tantangan industri, dan suasana kerja yang kreatif. Tugas manajemen sekolah adalah memfasilitasi terpenuhinya factor-faktor kunci tersebut.

\section{SIMPULAN DAN SARAN}

Para peneliti terus mempelajari tentang pengetahuan sebagai sumber daya sekolah yang penting. Bisa dikatakan bahwa knowledge sharing, baik tacit maupun explicit knowledge mampu meningkatkan kinerja sekolah secara signifikan. Organizational culture mengubah pengetahuan individu menjadi pengetahuan sekolah. Penelitian ini menyimpulkan bahwa organizational culture berperan sebagai katalisator dari proses knowledge sharing di antara guru di sekolah. Budaya knowledge sharing ini menjadi hal krusial di tengah perkembangan masyarakat pengetahuan saat ini. Karena sejatinya, guru lah yang mengemban kewajiban mempersiapkan anak didik mereka untuk belajar dan bekerja dalam masyarakat pengetahuan ini. Penelitian ini memiliki beberapa keterbatasan. Pertama, penelitian ini menganalisis pengaruh tacit dan explicit knowledge terhadap teacher innovation capability guru, baik secara langsung maupun secara tidak langsung melalui variabel organizational culture. Karena 
mungkin ada beberapa variabel lain yang mempengaruhi teacher innovation capability, penulis sangat menyarankan untuk menemukan, mengeksplorasi dan menganalisisnya. Kedua, penelitian ini dilakukan di lingkungan lembaga pendidikan sekolah dan mungkin tidak dapat digeneralisasi untuk industri lain. Oleh karena itu sangat disarankan dilakukan penelitian lebih lanjut tentang topik ini di industri lain.

\section{DAFTAR RUJUKAN}

Afsar, B., Masood, M., \& Umrani, W. A. 2019. The role of job crafting and knowledge sharing on the effect of transformational leadership on innovative work behavior. Personnel Review. doi:10.1108/pr-04-2018-0133

Al-Kurdi, O., El-Haddadeh, R., \& Eldabi, T. 2018. Knowledge sharing in higher education institutions: a systematic review. Journal of Enterprise Information Management, 31(2), 226-246. doi:10.1108/jeim-09-2017-0129

Asbari, M., Purwanto, A., \& Santoso, P. B. 2019. Influence of Leadership, Motivation, Competence, Commitment and Culture on ISO 9001:2015 Performance in Packaging Industry. Scholars Journal of Economics, Business and Management, 6(12), 577-582. https://doi.org/10.36347/sjebm.2019.v06i12.005

Asbari, M., Purwanto, A., Maesaroh, S., Hutagalung, D., Mustikasiwi, A., Ong, F., \& Andriyani, Y. 2020. Impact of Hard Skills, Soft Skills and Organizational Culture : Lecturer Innovation Competencies As Mediating. EduPsyCouns: Journal of Education, Psychology and Counseling, 2(1), 142-155. https://ummaspul.ejournal.id/Edupsycouns/article/view/419

Bani-Melhem, S., Zeffane, R. and Albaity, M. 2018. "Determinants of employees' innovative behavior", International Journal of Contemporary Hospitality Management, Vol. 30 No. 3, pp. 1601-1620. https://doi. org/10.1108/IJCHM-02-2017-0079

Culot, G., Orzes, G., \& Sartor, M. 2019. Integration and scale in the context of Industry 4.0: the evolving shapes of manufacturing value chains. IEEE Engineering Management Review, 1-1. doi:10.1109/emr.2019.2900652

Ghozali, I. 2014. Structural Equation Modeling, Metode Alternatif dengan Partial Least Square (PLS), Edisi 4. Semarang: Badan Penerbit Universitas Diponegoro.

Gunasekaran, A., Subramanian, N., \& Ngai, E. 2018. Quality Management in the 21st Century Enterprises: Research pathway towards Industry 4.0. International Journal of Production Economics. doi:10.1016/j. ijpe.2018.09.005

Haamann, T., \& Basten, D. 2018. The role of information technology in bridging the knowing-doing gap: an exploratory case study on knowledge application. Journal of Knowledge Management. doi:10.1108/jkm-012018-0030

Hair, J. F., Black. W. C., Babin. B. J.; and Anderson. R. E. 2010. Multivariate Data Analysis, 7th ed. New Jersey: Pearson Prentice Hall.

Hamada, T. 2019. Determinants of Decision-Makers' Attitudes toward Industry 4.0 Adaptation. Social Sciences, 8(5), 140. doi:10.3390/socsci8050140

Hartley, J. 2018, “Ten propositions about public leadership", International Journal of Public Leadership, Vol. 14 No. 4, pp. 202-217. https://doi.org/10.1108/IJPL-09-2018-0048

Hodgins, M. and Dadich, A. 2017. "Positive emotion in knowledge creation", Journal of Health Organization and Management, Vol. 31 No. 2, pp. 162-174. https://doi.org/10.1108/JHOM-06-2016-0108

Holste, J. S., \& Fields, D. 2010. Trust and tacit knowledge sharing and use. Journal of Knowledge Management, 14(1), 128-140. doi:10.1108/13673271011015615

Hussain, S. T., Lei, S., Akram, T., Haider, M. J., Hussain, S. H., \& Ali, M. 2018. Kurt Lewin's change model: A critical review of the role of leadership and employee involvement in organizational change. Journal of Innovation \& Knowledge, 3(3), 123-127. doi:10.1016/j.jik.2016.07.002

Hutagalung, D., Sopa, A., Asbari, M., Cahyono, Y., Maesaroh, S., \& Chidir, G. 2020. Influence of Soft Skills, Hard Skills and Organization Learning on Teachers' Performance through Innovation Capability as Mediator. Journal of Critical Reviews, 7(19), 54-66. http://www.jcreview.com/?mno=101978

Imran, M., Ilyas, M., Aslam, U. and Fatima, T. 2018. "Knowledge processes and firm performance: the mediating effect of employee creativity", Journal of Organizational Change Management, Vol. 31 No. 3, pp. 512-531. https://doi.org/10.1108/JOCM-10-2016-0202

Jiménez-Jiménez, D., \& Sanz-Valle, R. 2011. Innovation, organizational culture, and performance. Journal of Business Research, 64(4), 408-417. doi:10.1016/j.jbusres.2010.09.010

Jou, M. Lin, Y. and Wu, D. 2016. Effect of a blended learning environment on student critical thinking and knowledge transformation, Interactive Learning Environments, 24:6, 1131-1147, DOI: 10.1080/10494820.2014.961485 
Kim, N. and Shim, C. 2018. Social capital, knowledge sharing and innovation of small- and medium-sized enterprises in a tourism cluster. International Journal of Contemporary Hospitality Management, Vol. 30 No. 6, pp. 2417-2437. https://doi.org/10.1108/IJCHM-07-2016-0392

Klaeijsen, A., Vermeulen, M., \& Martens, R. 2017. Teachers' Innovative Behaviour: The Importance of Basic Psychological Need Satisfaction, Intrinsic Motivation, and Occupational Self-Efficacy. Scandinavian Journal of Educational Research, 62(5), 769-782. doi:10.1080/00313831.2017.1306803

Lecat, A., Beausaert, S. \& Raemdonck, I. 2018. On the Relation Between Teachers' (In)formal Learning and Innovative Working Behavior: the Mediating Role of Employability. Vocations and Learning 11, 529-554. doi:10.1007/s12186-018-9199-x

Lee, Peter. 2019. Tacit Knowledge and University-Industry Technology Transfer. Research Handbook on Intellectual Property and Technology Transfer (2019, Forthcoming); UC Davis Legal Studies Research Paper Forthcoming. doi: http://dx.doi.org/10.2139/ssrn.3417933

Li, M., Liu, H. and Zhou, J. 2018. "G-SECI model-based knowledge creation for CoPS innovation: the role of grey knowledge", Journal of Knowledge Management, Vol. 22 No. 4, pp. 887-911. https://doi.org/10.1108/ JKM-10-2016-0458

Li, Song, Wang, \& Li. 2019. Intellectual Capital, Knowledge Sharing, and Innovation Performance: Evidence from the Chinese Construction Industry. Sustainability, 11(9), 2713. doi:10.3390/su11092713

Liebowitz, J. and Chen, Y. 2001. Developing knowledge-sharing proficiencies. Knowledge Management Review 3(6): 12-15. https://www.researchgate.net/publication/ 285908349_Developing_knowledge-sharing_ proficiencies_Building_a_supportive_culture_for_knowledge-sharing

Lin, C.-P. 2006. To Share or Not to Share: Modeling Tacit Knowledge Sharing, Its Mediators and Antecedents. Journal of Business Ethics, 70(4), 411-428. doi:10.1007/s10551-006-9119-0

Lin, H., Lee, Y. 2017. A Study of The Influence of Organizational culture on Employees' Innovative Behavior and Work Engagement by A Cross-Level Examination. Eurasia Journal of Mathematics, Science and Technology Education, 13(7), 3463-3478. https://doi.org/10.12973/eurasia.2017.00738a

Lombardi, R. 2019. Knowledge transfer and organizational performance and business process: past, present and future researches. Business Process Management Journal, 25(1), 2-9. doi:10.1108/bpmj-02-2019-368

Ma, Q., Mayfield, M. and Mayfield, J. 2018, "Keep them on-board! How organizations can develop employee embeddedness to increase employee retention", Development and Learning in Organizations, Vol. 32 No. 4, pp. 5-9. https://doi.org/10.1108/DLO-11-2017-0094

Martínez-Costa, M., Jiménez-Jiménez, D., \& Dine Rabeh, H. A. 2018. The effect of organisational learning on interorganisational collaborations in innovation: an empirical study in SMEs. Knowledge Management Research \& Practice, 1-14. doi:10.1080/14778238.2018.1538601

Muñoz, C.A., Mosey, S. and Binks, M. 2015. The tacit mystery: reconciling different approaches to tacit knowledge. Knowledge Management Research \& Practice, 13:3, 289-298, DOI: 10.1057/kmrp.2013.50

Muscio, A., \& Ciffolilli, A. 2019. What drives the capacity to integrate Industry 4.0 technologies? Evidence from European R\&D projects. Economics of Innovation and New Technology, 1-15. doi:10.1080/10438599.2019 .1597413

Muthuveloo, R., Shanmugam, N., \& Teoh, A. P. 2017. The impact of tacit knowledge management on organizational performance: Evidence from Malaysia. Asia Pacific Management Review, 22(4), 192-201. doi:10.1016/j. apmrv.2017.07.010

Nonaka I., Toyama R. 2015. The Knowledge-creating Theory Revisited: Knowledge Creation as a Synthesizing Process. In: Edwards J.S. (eds) The Essentials of Knowledge Management. OR Essentials Series. Palgrave Macmillan, London. https://doi.org/10.1057/9781137552105_4

Nugroho, M. 2018. "The effects of collaborative cultures and knowledge sharing on organizational culture", Journal of Organizational Change Management, Vol. 31 No. 5, pp. 1138-1152. https://oi.org/10.1108/ JOCM-10-2017-0385

Parida, V., Sjödin, D., \& Reim, W. 2019. Reviewing Literature on Digitalization, Business Model Innovation, and Sustainable Industry: Past Achievements and Future Promises. Sustainability, 11(2), 391. doi:10.3390/ su11020391

Polanyi, M. 1966. The Tacit dimension. New York: Doubleday \& Co.

Qi, C. and Chau, P.Y.K. 2018. Will enterprise social networking systems promote knowledge management and organizational culture? An empirical study, Journal of Organizational Computing and Electronic Commerce, 28:1, 31-57, DOI: 10.1080/10919392.2018.1407081 
Rothberg, H. and Erickson, G. 2017. "Big data systems: knowledge transfer or intelligence insights?", Journal of Knowledge Management, Vol. 21 No. 1, pp. 92-112. https://doi.org/10.1108/JKM-07-2015-0300

Santoro, G., Vrontis, D., Thrassou, A., \& Dezi, L. 2017. The Internet of Things: Building a knowledge management system for open innovation and knowledge management capacity. Technological Forecasting and Social Change. doi:10.1016/j.techfore.2017.02.034

Sousa, M. J., \& Rocha, Á. 2019. Strategic Knowledge Management in the Digital Age. Journal of Business Research, 94, 223-226. doi:10.1016/j.jbusres.2018.10.016

Stachová, K., Papula, J., Stacho, Z., \& Kohnová, L. 2019. External Partnerships in Employee Education and Development as the Key to Facing Industry 4.0 Challenges. Sustainability, 11(2), 345. doi:10.3390/ su11020345

Starbuck, W. 2017. “Organizational culture and unlearning”, The Learning Organization, Vol. 24 No. 1, pp. 30-38. https://doi.org/10.1108/TLO-11-2016-0073

Tang, V., Yanine, F. and Valenzuela, L. 2016, "Data, information, knowledge and intelligence: The mega-nano hypothesis and its implications in innovation", International Journal of Innovation Science, Vol. 8 No. 3, pp. 199-216. https://doi.org/10.1108/IJIS-07-2016-0022

Terhorst, A., Lusher, D., Bolton, D., Elsum, I., \& Wang, P. 2018. Tacit Knowledge Sharing in Open Innovation Projects. Project Management Journal, 49(4), 5-19. doi:10.1177/8756972818781628

Triwiyanto, T., Suyanto., \& Prasojo, L. D. 2019. The Thoughts of Ki Hadjar Dewantara and Their Implications for School Management in the Industrial Era 4.0. International Journal of Innovation, 5(4), 12.

Urban, B. and Gaffurini, E. 2018. "Social enterprises and organizational culture in South Africa", Journal of Entrepreneurship in Emerging Economies, Vol. 10 No. 1, pp. 117-133. https://doi.org/10.1108/JEEE-022017-0010

Wang, C., Chen, M. and Chang, C. 2019. "The double-edged effect of knowledge search on innovation generations", European Journal of Innovation Management. Vol. ahead-of-print No. ahead-of-print. https://doi.org/10.1108/ EJIM-04-2018-0072

Wang, J., \& Liu, L. 2019. Study on the mechanism of customers' participation in knowledge sharing. Expert Systems, e12367. doi:10.1111/exsy.12367

Wang, X., Arnett, D. and Hou, L. 2016. "Using external knowledge to improve organizational innovativeness: understanding the knowledge leveraging process", Journal of Business \& Industrial Marketing, Vol. 31 No. 2, pp. 164-173. https://doi.org/10.1108/JBIM-04-2014-0064

Wang, Z., \& Wang, N. 2012. Knowledge sharing, innovation and firm performance. Expert Systems with Applications, 39(10), 8899-8908. doi:10.1016/j.eswa.2012.02.017

Widmann, A. and Mulder, R. 2018. "Team learning behaviours and innovative work behaviour in work teams", European Journal of Innovation Management, Vol. 21 No. 3, pp. 501-520. https://doi.org/10.1108/EJIM-122017-0194

Xu, M., David, J. M., \& Kim, S. H. 2018. The Fourth Industrial Revolution: Opportunities and Challenges. International Journal of Financial Research, 9(2), 90. doi:10.5430/ijfr.v9n2p90

Yang, Z., Nguyen, V. and Le, P. 2018. Knowledge sharing serves as a mediator between collaborative culture and teacher innovation capability: an empirical research, Journal of Business \& Industrial Marketing, Vol. 33 No. 7, pp. 958-969. https://doi.org/10.1108/JBIM-10-2017-0245

Zhu, Q., Krikke, H. and Caniëls, M. 2018. Supply chain integration: value creation through managing interorganizational culture. International Journal of Operations \& Production Management, Vol. 38 No. 1, pp. 211-229. https://doi.org/10.1108/IJOPM-06-2015-0372 